\title{
Møter med suicidale klienter i en barne- og ungdomspsykiatrisk poliklikk
}

Ved Ingebjørg Hestetun

\section{Barne- og ungdomspsykiatrien har ansvar for å gi behandlingstilbud til barn \\ og unge under 18 år. I 2005 var det i Norge registrert 1490 pasienter i barne- og ung-}

domspsykiatrien med suicidalfare som viktigste henvisningsgrunn (Pedersen, 2005, s.202). Mange av våre unge pasienter strever også med selvmordstanker og -impulser uten at dette er registrert som henvisningsgrunn, men de kan komme fram underveis i behandlingskontakten. Selv om få av disse unge oppfattes å være i akutt fare for å ta livet sitt, er vurdering og oppfølging av unge mennesker med suicidaltanker og -impulser et viktig område i barne- og ungdomspsykiatrien. I denne artikkelen viser jeg til erfaringer jeg har fått i møte med denne klientgruppa ved en barne- og ungdomspsykiatrisk poliklikk. Kliniske eksempler er anonymisert.

\section{Hvorledes kan vi vite om en} ungdom er i risiko for selvmord?

$M$ ange forhold gir en økt risiko for selvmordsatferd. Vi finner blant annet en økt forekomst av psykiske lidelser, belastninger og negative livshendelser som seksuelle og fysiske overgrep, rusmisbruk, og fravær av sosial støtte. Typiske eksempler på utøøsende faktorer er kjærestebrudd, konflikter i forhold til foreldre eller venner, problem på skolen eller lovbrudd. Fordi risikofaktorer for selvmord er så vanlige, og de fleste unge på ulik måte klarer à forholde seg til slike påkjenninger uten å ta livet sitt, er det ikke mulig på bakgrunn av risikofaktorer å forutsi selvmord. Risikofaktorer kan bare gi oss en pekepinn. Det finnes heller ikke pålitelige skalaer eller instrumenter for vurdering av selvmordsfare hos ungdom. Vi må spørre. Først med utgangspunkt i ei inngående samtale kan vi vurdere selvmordsfare hos den enkelte.

\section{Vi må samtale med de unge}

Selvmordstanker er vanligvis ikke uttrykk for et ønske om å dø, selvmord representerer et negativt alternativ som blir aktuelt når livet oppleves for vanskelig. $\mathrm{N}$ år en ungdom snakker med oss, kan det derfor oppfattes som uttrykk for at livet gis en mulighet. Samtidig må selvmordstankene eller -forsøket tas på alvor, som uttrykk for at smerten ved å leve blei for stor. Den unge møter oss heller ikke for å bli vurdert, men med et håp eller ønske om å bli forstått. M ed dette som utgangspunkt kan vi sammen med den unge ta opp det som er vanskelig, og samtale om i hvilken grad det også foreligger fare for at den unge kan ta livet sitt. I ei slik samtale bør en være åpen og direkte. Eksempler på spørsmål kan være: "H ar du det så vanskelig at du opplever at du ikke orker å leve? H ar du tenkt å ta ditt eget liv?" Vi setter ikke barn og ungdom på tanken ved å spørre, men viser at dette kan vi snakke om.

I en mulig akuttsituasjon er vi ikke opptatt av "å vite alt", men av å få tilstrekkelig informasjon til at vi kan vurdere selvmordsfare. Spesielt gjelder dette opplysninger om:

\section{A ktuelle selvmordsplaner og tilgjengelig metode}

Dersom det foreligger konkrete planer om selvmord, er faren selvsagt langt høyere enn om en har tenkt på selvmord som en muligutvei, men ikke har planlagt dette nå. Vi må spørre den unge og foreldrene om medikamenter og våpen oppbevares i heimen, og i så fall sikre at disse er forsvarlig nedlåst. M ange unge tar livet sitt med usikra våpen. B ruk av medikamenter er svært vanlig ved selvmordsforsøk, og flere unge tar hvert år livet sitt ved forgiftning. U ngdom er ofte mer impul sive enn oss voksne, det gjelder også suicidalhandlinger. Brukes våpen er det farlig.

Ei jente opplevde et traume, var fortvilt og impul siv, ville der og da bare komme vekk, fant et handvåpen, trakk av, det sa klikk, hun hadde ikke ladd våpenet ordentlig. H un sa: "Klikket gjorde at jeg kom til meg selv - jeg ville jo ikke ta livet mitt". N å sier hun at det er bra om jeg forteller om hennes erfaring, for å understreke viktigheten av at våpen er forsvarlig nedlåst. I 2003 sendte Sosial- og helsedirektoratet ut et rundskriv for å minne om helsepersonells plikt til å ta opp dette.

\section{- Foreligger det tidligere selvmordsforsøk?} I så fall kan det tyde på at selvmordshandlinger er en måte å reagere på ved store vanskeligheter. 0 gså sel vmordsatferd hos nærstående øker risiko.

- A ktuelle vanskeligheter og psykiske lidelser Selvmordstanker og atferd er nesten alltid relatert til en situasjon. Snakk om hva som har skjedd og hvilke tanker og følelser som den unge sliter med. $\mathrm{N}$ oen kan ikke peke på noe konkret som har hendt akkurat nå, men opplever at det over lang tid er blitt for mye som oppleves vanskelig. A v og til kommer det fram opplysninger om belastninger i den aktuelle situasjonen som en må gripe raskt tak i, som overgrep, ydmykende hendelser etc. Enkelte unge har symptomer som er relatert til psykisk lidelse, og som oppleves skremmen de eller vanskelig å leve med. Problemer med impulskontroll eller følelsesmessig ustabilitet, alvorlig psykisk lidelse og rusproblemer gir økt risiko for selvmord. I hvilken grad disse foreligger, må også vurderes.

\section{- Sosial støtte}

Som regel er foreldrene de viktigste støttepersonene for barna sine. På hvilken måte kan foreldrene gi hjelp, og er den unge i stand til å ta i mot dette? Er det et sosialt nettverk for øvrig som kan gi støtte? $\mathrm{H}$ va kan den unge gjøre når vanskelige tanker eller impul ser presser på? Kan vedkommende snakke med foreldrene eller giøre noe sammen med andre? $\mathrm{V}$ ær konkret med hensyn til ulike alternativer. $0 \mathrm{fte}$ vil betydningen av venner trekkes fram. De kan være viktige støtter, men venner skal aldri gis ansvar for en ungdom som sliter med sel vmordsimpulser.

Dersom det foreligger konkrete selvmordsplaner og midler til å gjennomføre disse er til gjengelige, er faren for selvmord høy. Enkelte unge har derfor behov for 


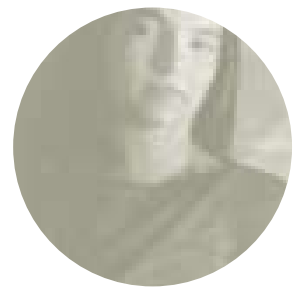

akutt innleggelse. Ofte vil poliklinisk oppfølging være tilstrekkelig, forutsatt at foreldre kan ta vare på den unge i en krisesituasjon og ved behov formidle kontakt med hjelpeapparatet. I så fall er det viktig å snakke konkret om hva en gjør dersom selvmordsimpulser igjen blir sterke. Hvem kan den unge gå til? Ofte er dette foreldrene, men også andre personer kan være viktige st $\varnothing$ ttepersoner. Hva gjør den unge dersom vedkommende ikke er å få tak i? Er det noen andre det går an å ringe til eller opps $\varnothing k e$ ? Når er den barne- og ungdomspsykiatriske poliklinikken åpen, og kan en få snakke med en fagperson der? Legevakt? Gi konkret informasjon og gjerne opplysning om aktuelle telefonnummer. Raskt poliklinisk oppfølgingstilbud og samarbeid med foreldre er også viktig for å redusere risiko for at behandling avbrytes for tidlig, noe som ofte er et problem.

Nina på 15 år opplevde ei krise. Hun var deprimert, hadde selvmordstanker, og en kveld blei ekstra tung. Hun ringte en hjelpetelefon. I timen hos meg neste dag snakket hun om hva som hadde hjulpet henne: $\mathrm{H}$ an hørte på meg, han ville forstå, han hadde tid, det hjalp å snakke. Vi kan legge til:

Hun møtte et engasjert medmenneske som også viste henne muligheten av å komme videre, og gjorde avtale med henne om hva hun skulle gjøre dagen etter - snakke med meg. Det blei ikke gitt klare råd eller presentert løsninger ut over dette, samtala hadde likevel vært svært viktig.

Hva som kan hjelpe, må en ofte bruke tid på å finne ut. Ikke vær urealistisk positiv. Når en ungdom er i krise vil vi så gjerne gi noe, og det er lett å komme med mange tilsynelatende gode forslag. Dersom vi hopper for raskt på løsninger, vil den unge lett få en opplevelse av ikke å være forstått, ikke bli tatt på alvor, og oppleve dette som en avvisning. Slike forslag kan også være uttrykk for vårt ønske om å benekte det alvorlige eller smertefulle innholdet i historien som vi faktisk blir presentert for. Unntaksvis finnes enkle løsninger, vanligvis er heller ikke det tilfellet. Gjennom våre spørsmål kan vi likevel åpne opp for en utvida forståelse i en situasjon som ellers oppleves fastlåst, slik at den unge selv lettere ser muligheter.

\section{Behandling}

Unge med selvmordstanker er forskjellige og behandlingsopplegg må tilpasses den enkelte, avhengig av problematikk og situasjon. For noen unge er selvmordsatferden i stor grad relatert til en utløsende hendelse. Her har vi den impulsive jenta som opplevde at kjæresten ville slå opp, og som i en akutt situasjon fors $\varnothing$ kte å ta livet sitt. Hun blei stoppa av venner, og fant raskt ut at den tidligere kjæresten ikke var verdt at hun skulle $\mathrm{d} \varnothing$ på grunn av han.

Det kan være aktuelt å tilby hjelp i en krisesituasjon, selv om det ikke er behov for langvarig behandlingstilbud.

Noen unge har omfattende vansker og sliter med selvmordsimpulser over tid.

Thomas strevde med depresjon, aggressivitet, suicidalimpulser og selvskadende handlinger. Han formidlet en opplevelse av håpløshet og at alt virket umulig, og han skjønte ikke hvorfor. Thomas opplevde st $\varnothing$ tte fra kamerater, dette hjalp han i ei vanskelig periode. Han var i utgangspunktet en gutt med mange ressurser, det var derfor lett å overse hvorledes han strevde med å forholde seg til hva andre ville oppfatte som enkle vansker. I behandlingsopplegg med Thomas tok vi utgangspunkt i situasjoner da han hadde reagert med sinne eller selvskading, ofte begge deler. Gjennom konkrete analyser fors $\varnothing$ kte vi å finne ut hvorledes dette hang sammen med erfaringer han hadde hatt, hans følelsesmessige reaksjoner og alternative måter å forholde seg på. Thomas sa om dette at "det er lettere å være deprimert når jeg skjønner hvorfor". I tillegg til individuell kontakt hadde vi et nært samarbeid med foreldre, skole og fastlege. Thomas hadde også nytte av medikasjon.

Alvorlige vansker hadde også Kristina som på ny opplevde ei suicidalkrise og tok kontakt. Hun sa: "Hva kan jeg gjøre, hjelp meg", og "det er som om jeg står på en stor haug og roper, og ingen hører for de tenker at det er bare Kristina”. Som behandlere er vi opptatt av ikke å forsterke uhensiktsmessig atferd. Av den grunn kan vi komme til å overse eller avvise Kristina i den aktuelle situasjonen, i stedet for å spørre oss om hva hun vil formidle.

Hva villet egenskade er uttrykk for, er ei viktig problemstilling i en stor europeisk unders $\varnothing$ kelse der også Norge deltok (Ystgaard, 2003). Her spurte en ungdom i videregående skole om de noen gang hadde skadet seg med vilje. $10,7 \%$ av de unge opplyste at de hadde gjort dette. De unge blei også spurt om hvorfor de hadde skadet seg selv. Flere svar var mulig. Over halvparten av de norske ungdommene som opplyste at de hadde skadet seg selv, oppga at de $\varnothing$ nsket å d $\varnothing$ da de skadet seg. Slippe uutholdelig følelse blei oppgitt av nesten to tredeler. Straffe seg selv var også vanlig. Ønske om å få oppmerksomhet blei oppgitt av 19,2\%, men var sjelden hovedgrunn til at unge skadet seg selv. Vi som behandlere kan i våre møter med unge suicidale bli opptatt av kommunikasjon i forbindelse med selvmordsatferd eller villet egenskade. Slike motiv finner vi også, selv om de ikke dominerer. Når en ungdom tyr til en slik desperat handling for å få oppmerksomhet eller for å finne ut om noen er glad i seg, er det viktig at vi også forstår og forholder oss til det, som Kristina i eksemplet over ber om. Men i den grad vi făr tanker om at det er manipulasjon, må vi spørre om dette er den unges motiv, eller om det kanskje heller dreier seg om vår egen eller omgivelsenes opplevelse av avmakt i møte med unge suicidale. For Kristina var selvmordshandlinger uttrykk for både hennes smerte og et fors $\varnothing \mathrm{k}$ på å kommunisere sitt behov for hjelp. Hun hadde ikke andre strategier, og ville derfor fortsette å rope til noen hørte henne eller ty til selvmordsatferd for å komme unna smerten som hun opplevde.

Kristina hadde begrensa mestringsstrategier til å hjelpe seg med i situasjoner der hun møtte motgang. Gjennom forskning har en vist at mennesker med selvmordsatferd ofte har svakere problemløsningsevne, spesielt når det gjelder vanskeligheter i mellommenneskelige forhold (Williams, 2002). Dette vil være et viktig behandlingsfokus i arbeid med unge som Kristina. 


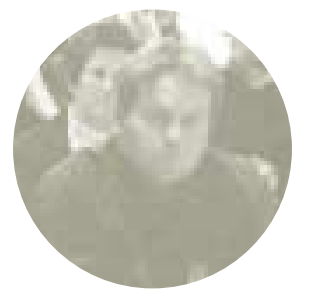

\section{Foreldre er en viktig ressurs}

I vår kontakt med unge suicidale er det viktig å ha et samarbeid med foreldrene. O ftest vil foreldrene ønske et samarbeid med behandlere på grunn av sin omsorg og bekymring for den unge, og for å få hjelp i sin oppgave som foreldre. Støtte og oppfølging fra foreldre kan også i noen situasjoner bety at innleggelse ikke er nødvendig selv om den unge strever med sterke suicidalimpulser.

I den grad vi erfarer tilbakeholdenhet fra foreldre kan dette henge sammen med opplevelse av å være mislykket som foreldre, skyld og skam, angst for endring eller for innsyn i familien. Da er det spesielt viktig at foreldrene får hjelp til å se betydningen av sin ivaretakelse av sønnen eller datteren. Etter et suicidforsøk kan også den umiddel bare lettelsen over at det likevel gikk bra, medføre at behov for hjelp undervurderes. D en unge kan ha ønske om å berolige foreldrene, selv oppleve skyldfølelse over forsøket og av den grunn ønske å bagatellisere, og være optimistisk fordi mor og far har skjønt at han/hun har det vanskelig. $N$ å skal vi ikke undervurdere familiens egne mestringsressurser. $M$ en i en krisesituasjon ligger en mulighet til reorganisering og endring, en større åpenhet til å orientere seg på nytt. O gså der det ikke er behov for et behandlingstilbud over tid, kan det være viktig å følge familien ei stund framover til en ser at det fortsatt går bra.

Som behandlere kan vi også være opptatt av "hva gikk galt". Dette vil støtte opp under foreldrenes skyldfølelse og øke sjansen for at vi mister både foreldrene og barnet/ungdommen. Det er mulig at foreldrene ikke har ivaretatt sin oppgave som omsorgspersoner på en god nok måte. Foreldrene kan ha sine problemer. Det er også mulig at den unge har vært utsatt for overgrep heime. Slike forhold må vi selvsagt gripe tak i. U nntaksvis kan det være riktig ikke å trekke inn foreldrene, men kanskje kontakte barnevernet i stedet. $M$ en dersom vi tenker dette uten å ha nærmere informasjon, kan vi gjøre både den unge og foreldrene en stor urett. $\mathrm{Vi}$ trenger foreldrene som samarbeidspartnere når det gjelder å hjelpe den unge videre i livet.

Så kan det være at en ungdom sier nei til at vi skal kontakte foreldrene om be- handlingstilbudet. En ungdom over 16 år kan vanligvis bestemme dette selv. $\mathrm{H}$ er er det unntak når slik informasjon er nødvendig for at foreldrene skal ivareta sin foreldrefunksjon. Ved alvorlig selvmordsfare har vi vanligvis plikt til å informere foreldrene. (For en drøfting av dette, se utredningen Rutiner for registrering, behandling og oppfølging av pasienter innlagt i norske sykehus etter parasuicid (Statens helsetil syn, 2001)). H vilken informasjon som gis, bør vi snakke med den unge om på forhånd. 0 ftest vil dette skape større trygghet for slike felles samtaler. G rete representerer her et unntak.

G rete bodde på hybel og gikk på videregående skole et stykke unna foreldrene. $H$ un blei lagt inn på sykehus etter et selvmordsforsøk. Som betingelse for utskriving var det nødvendig å sikre at det fantes et nettverk rundt $\mathrm{G}$ rete slik at hun blei fulgt opp dagl ig den første tida, og hun også visste hvor hun kunne henvende seg dersom hun fikk tanker som hun hadde vansker med å forholde seg til. G rete var 17 år og motsatte seg at foreldrene skulle kontaktes. H un opplyste om en komplisert heimesituasjon, av den grunn ga barnevernet et hjel petilbud. På bakgrunn av informasjon fra $G$ rete og i samarbeid med barnevernet blei G rete sikret tett oppfølging fra ulike lokale instanser der hun nå bodde på hybel, i tillegg tok hun imot et poliklinisk tilbud fra BU P.

\section{Barn og selvmord}

Det var tidligere en vanlig oppfatning at yngre barn har svært begrensa eller manglende kunnskap om selvmord, og at de derfor heller ikke var i risiko for å ta livet sitt. Vi veit også at små barn har begrensa forståelse av hva døden innebærer. Små barn kan for eksempel ha en idé om døden som likner på à sove, og der døden er reversibel. Vi kjenner alle eventyret om Tornerose som blei vekt opp igjen av prinsen etter 100 år. Likevel ser det ut til at også yngre barn har kjennskap til selvmord. I en undersøkelse av dette fant en at barn vanligvis alt i 6-8årsal deren hadde utviklet en oppfatning av hva selvmord innebærer, selv om de yngste barna ikke alltid kjenner ordet selvmord. De visste at ei selvmordshandling fører til døden, de hadde begrep om døden som en permanent tilstand, og kunne opplyse om måter å ta livet sitt på (M ishara, 1999).

Selvmordsatferd innebærer en skadelig atferd, og en idé om å ta livet sitt. D ette forutsetter ikke nødvendigvis at et barn har begrep om døden som en endelig tilstand, men en idé om døden som en måte å komme vekk eller få til ei forandring på. Dette var maktpåliggende for Petter.

Petter opplevde en konfliktsituasjon som for han virket uløselig, og kunne tenkes å gjøre en desperat handling for å komme unna. M oren til Petter fikk kontakt med BU P etter at han hadde sagt: "Jeg vil dø, jeg vil til Kina." M oren var bekymra for at Petter kunne ta livet sitt. Fordi Petter blei tatt på alvor av moren sin, fikk snakket om det som var vanskelig og fikk hjelp til endring, blei det raskt avklart at han ikke ville dø, men hadde behov for hjelp til hvorledes han skulle klare å leve.

Barn tar sjel den livet sitt. M en våre oppfatninger om at yngre barn ikke har begrep om selvmordsatferd og ikke forstår hva døden innebærer, kan føre til at vi ikke fanger opp selvmordstanker eller -atferd når dette forekommer. Enkelte selvmord blant barn kan feilaktig oppfattes som ulykker. Eksempler er enkelte tilfeller av forgiftning eller der et barn tilsynelatende umotivert hopper fra et høyt sted.

BU P fikk henvendelse om en gutt på 7 år som kom inn på barneavdelingen etter at han hadde tømt et glass med vitamintabletter. Foreldrene fortalte på sjukehuset at sønnen feilaktig trodde det var drops.

Sjukehuspersonalet opplevde en trist gutt - som etter hvert fortalte at han ikke orka leve lenger - og da kunne en ta tabletter. M edisinsk sett var dette et lite alvorlig forsøk. M en fra guttens perspektiv var det ei alvorlig handling, med bakgrunn i omsorgssvikt som nå kom fram. 
villet egenskade

\section{$\AA$ v være behandler}

Selvmord er en av de vanligste dødsårsakene blant ungdom. I 2004, som er det siste året vi har tilgjengelig statistikk fra, var det 11 gutter og 4 jenter under 18 år som tok livet sitt. De fleste var i alderen 15-17 år (Statistisk sentral byrå, 2006). Selv om vi ikke har oversikt over hvor mange av disse som var i kontakt med et hjel petilbud, risikerer vi alle å miste en pasient i selvmord. For å redusere risiko for at dette skal skje er kunnskap, gode rutiner for vurdering og oppfølging av unge suicidale avgjørende. Som behandlere er det også vesentlig at vi opplever et trygt arbeidsmiljø og støtte fra kollegaer. D ette gjør behandler mer åpen for å ta i mot unge med suicidal problematikk og bedrer kvaliteten i arbeidet. Slik trygghet og støtte er også vesentlig dersom vi skulle oppleve at en ungdom som vi har behandlingskontakt med, likevel ikke klarer å leve.

I akuttvurderinger er det en god regel å være to eller ha mulighet til å kontakte en kollega dersom en er i tvil. Dette reduserer risiko for å overse viktig informasjon. 0 gså i pågåen de behandlingsforløp kan suicidalimpulser bli mer påtrengende. I slike situasjoner har jeg flere ganger invitert en kollega med inn i samtale med min klient, eller blitt invitert med av en kollega i tilsvarende situasjon. $\mathrm{M}$ in erfaring er at pasienter oppfatter dette som uttrykk for omsorg og for å bli tatt på alvor. Dessuten fører det til at pasienten kjenner flere på poliklinikken, noe som gjør det lettere å henvende seg dit dersom det oppstår en akuttsituasjon.

\section{"Jeg bestemmer over mitt liv"}

Spesielt ungdom kan utfordre ossi forhold til problemstillinger knytta til retten til å vel ge sitt eget liv. "Jeg bestemmer over mitt liv. Det er mitt valg. Det har du ingen ting med." A utonomi og kontroll over eget liv, er viktig for ungdom. Det er det som i sin ytterste konsekvens blir utfordra i forhold til sporsmålet om selvmord. Dersom en ungdom også opplever liten tillit til voksenverdenen og føler at muligheten til å bli forstått og til å få hjelp ikke er til stede, kan vi få problemer med å komme i posisjon som hjel pere. I mitt møte med unge mennesker er jeg derfor opptatt av å vise at jeg anerkjenner den enkeltes rett til å bestemme hvorledes en vil leve sitt eget liv. Dette skilles fra min plikt til å gripe inn dersom jeg vurderer at den unge er i fare for å velge døden. U ngdom sier også at de ønsker voksne som er til stede, voksne som bryr seg, som er opptatt av å forstå, som tar de vanskene som de unge opplever på alvor, og som tåler å forhol de seg til de unges virkelighet.

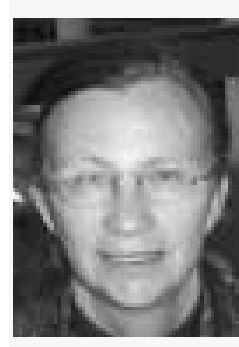

Ingebjørg $\mathrm{H}$ estetun er psykologspesialist ved SSFF og sjefpsykolog ved Barne- og ungdomspsykiatrisk seksjon Sykehuset Telemark H F. $\mathrm{H}$ un har mange års erfaring fra klinisk arbeid $i$ barne- og ungdomspsykiatrien.

\section{Referanser}

M ishara, B. (1999). Conceptions of death and suicide in children ages 6-12 and their implications for suicide prevention. Suicide Life Threat Behav. 29(2), 105-18

Pedersen, P.B. (red.) (2006). SA M DATA psykisk helsevern: sektorrapport 2005: sammenligningsdata for psykisk helsevern. Trondheim: SIN TEF H else. (N IS-rapport 2/06). H entet 2.11.2006 fra www.sintef.no/content/page13_ 7678.aspx

Sosial- og helsedirektoratet. (2003). H elsepersonells rett og/eller plikt til å gi informasjon til politi og militære myndigheter om pasienters helsetilstand. (Rundskriv IS-7/2003), datert 28.05.2003, sist endret 15.02.2006. Hentet 26.11.2006 fra www.shdir.no/publikasjoner/ rundskriv

Statens helsetilsyn. (2001). R utiner for registrering, behandling og oppfølging av pasienter innlagt i norske sykehus etter parasuicid: samarbeid mellom spesialist- og primærhelsetjenesten. (2001). (U tredningsserie / Staten s helsetilsyn; 3-01, IK-2743) Hentet 26.10.2006 fra www.helsetilsynet.no/templates/ A rticleW ithLinks_3454.aspx

Statistisk sentral byrå. (2006). D ødsårsaker 2004 H entet 26.10.2006 fra www.ssb.no/dodsarsak/

W illiams, J. M ark G . (2002). Psykologiske aspekter ved suicidal atferd. Suicidologi,7(1), 10-12

Ystgaard, M . (2003). V illet egenskade blant ungdom: nye forskningsresultater og konsekvenser for forebyggende arbeid.

Suicidologi, 8(2):7 -10. H entet 2.11.2006 fra http://www.med.uio.no /ipsy/ssff/suicidologi/ 2003-nr2/Ystgaard.pdf
Det er årlig ca 3-9 \% av tenåringer i en normalpopulasjon som oppgir å ha gjort et selvmordsforsøk eller har utført en villet egenskade. Det er kjent at det er svært høy risiko for selvmord blant disse ungdommene, og det er derfor presserende å utvikle gode behandl ingsformer for dem. I dag får de ofte et utilstrekkelig behandlingstilbud. Behandlingen av selvskaden de ungdom er meget krevende, og i tillegg er det mange som dropper ut av behandlingsopplegg som tilbys pr. i dag. Det er utviklet en behandlingsmetode, dial ektisk atferdsterapi (DBT), og en egen versjon av denne for ungdom, som gir grunnlag for optimisme.

Behandlingen er opprinnelig utviklet av $\mathrm{M}$ arsha Linehan, og bearbeidet for ungdom av A lec M iller. Det eksisterer for lite systematisk forskning omkring psykososiale intervensjoners effekt på ungdom med villet egenskade generelt, og det er et særdeles stort behov for å vurdere denne metodens effekt på selvskadende atferd og oppfølging av behandling spesielt.

SSFF planlegger en randomisert, kontrollert studie med ungdom i alderen

12-18 år som etter gjentatt villet egenskade med eller uten suicidintension, henvises for hjelp. Det planleggesinkludert totalt 150 ungdommer i henholdvis intervensjonsgruppen og i kontrollgruppen. $M$ ålet er å finne ut hva slags effekt DBT har i forhold til ordinær behandling som ungdom med villet egen skade får. Dette gjøres gjennom nøyaktig kartlegging av den enkelte ungdom før, under, og etter behandling, samt gjennom prosessorientert kunnskap omkring villet egenskade.

Terapeuter v/A ker og U Ilevål universitetssykehus er 2006/07 under DBT-utdanning. Denne tiden brukes bl.a. til å skaffe viktig info om implementering av behandlingen i $\mathrm{N}$ orge og til å få erfaringer med pasientgruppen.

Resultatene av studien vil ha nasjonal og internasjonal interesse. Det relativt store utval get, bruk av kontrollgruppedesign, kombinert med lite eksisterende litteratur på feltet, tilsier at prosjektet vil generere ny kunnskap. Et klinikknært prosjekt som dette vil også få avgjørende betydning for utviklingen av behandlingstilbud for ungdom med psykiske lidelser.

A nita I. Tørmoen dr.gradsstipendiat, SSFF 